\title{
TOURIST DESTINATIONS WITH ASYMMETRICAL LOCAL DEVELOPMENT: THE 'INTEGRALLY PLANNED TOURIST CENTRES' OF LOS CABOS AND LORETO, BAJA CALIFORNIA SUR (MEXICO)
}

\author{
A. MONTAÑO ${ }^{1}$, M. ANGELES ${ }^{2} \&$ J. PÉREZ \\ Department of Economics, Universidad Autónoma de Baja California Sur, México.
}

\begin{abstract}
The Centros Integralmente Planeados (Integrally Planned [tourism] centers, CIPs) are tourism development poles established in Mexico during the 1960s and 1970s so as to promote economic growth in (then) little - developed but natural resource and landscape - rich peripheral coastal regions. In this paper we look at the effects of tourism on local development in two CIPs, those of Los Cabos and Loreto, located in the state of Baja California Sur (BCS), in north-western Mexico. We employ an analytical- descriptive methodology, specifically principal-component analysis, which allows the contextualization of tourism evolution and development trajectories. Our results indicate the presence of asymmetrical development paths, even though both regions started from the same developmental initiative, with FONATUR (the Mexican government's tourism board) in charge in both cases. Forty years after its inception, the government's tourism policy yields differentiated results. Los Cabos has become a world-renowned destination, associated with sports fishing activities, golf, and residential tourism. In contrast, the Loreto- Nopoló- Puerto Escondido tourism corridor has stagnated and is still awaiting take-off into sustained development. Keywords:integrally planned tourist centres, local development, Mexico, tourism.
\end{abstract}

\section{INTRODUCTION}

In the 1970s Mexico embarked in a process of redefinition if public policies towards tourism. Isolated actions in support of traditional destinations were left behind in favour of a comprehensive planning model at the national level, orientated - mainly - to external markets. The new policy scheme materialised in a new concept, since then known as Centros Integralmente Planeados (Integrally Planned [Tourism] Centres, CIPs) [1]. Two strategies were followed in bolstering the new model. On the one hand, the expansion and improvement of traditional destinations, especially those having an important presence in international markets, such as Acapulco, Mazatlán, Manzanillo and Puerto Vallarta. At the same time, policy was directed toward the establishment of what became the country's most successful and innovative tourism promotion strategy, namely the construction of CIPs as development poles in new destinations based on the 'sun and beach' market concept, building the necessary infrastructure in enclaves of great natural and landscape value.

The beach sites that were developed as CIPs are (in order of creation): Cancún; Ixtapa-Zihuatanejo; Loreto; San José del Cabo; Huatulco and, most recently, Bahía Banderas, in the Pacific Coast state of Nayarit. These were all new urbanization projects, wherein it was sought to avoid the disorderly growth patterns already apparent in traditional tourist cities such as Acapulco. CIPs are an interesting case study of government-led tourism planning practices which Mexico pioneered in Latin America in order to overcome the great difficulties involved in the promotion of large-scale tourism in isolated beach spots in

${ }^{1}$ ORCID: https://orcid.org/0000-0002-2768-7776, amontano@uabcs.mx

${ }^{2}$ ORCID: http://orcid.org/0000-0003-1275-9535, manan@uabcs.mx 
a developing country [2]. It is, however, fair to say that CIPs were structured in such a way as to address primarily the economic needs of the tourism industry, and that they contemplated neither the social nor the environmental implications of tourist activities. The planning and investment required to guarantee a more balanced socio-spatial development was also lacking. Their creation and operation led to such high rates of growth and such large amounts of private sector investment that public sector investment in infrastructure and basic services lagged far behind, resulting in enormous pressures each region's on the land, natural resources and local population. While regions have benefited from the investment that served to detonate each tourism development pole, it is also true that tourism has greatly increased the demand for urban infrastructure and public and social services. Tourism land use has resulted in spatial demands that are now reducing the competiveness of most sites [3]. Over time, nonetheless, tourism has gained great importance for Mexico's economy, as shown by its growing contribution to GDP (8.7\% in 2016) and employment generation (5.9\%). CIPs account for $45 \%$ of the country's hotel rooms, and $42 \%$ of their customers are foreign tourists [4].

Mexico CIPs are in different stages of development. Some, notably Cancun and Los Cabos, have surpassed initial expectations; with the concomitant urban planning problems that fast growth brings along; most have not reached the growth rates expected [5]. These differences are in evidence in our two study cases, Los Cabos and Loreto. In Los Cabos, the initial scope of the development covered only the city of San José del Cabo, with future growth being contemplated only along the adjacent coastline. However, growth has been such that San José has been joined by a $33 \mathrm{~km}$.-long tourism corridor with Cabo San Lucas, $33 \mathrm{~km}$. to the southwest. Contrariwise, the Loreto CIP has not advanced at the rate that was foreseen upon its creation [6]. Research on tourism planning in Mexico in general and CIPs in particular, has shown that the large amount of investment wherever tourism has been developed has led to important social and environmental conflicts. In large part, this has been the result of centralised planning policies that has been unable to take into account such local characteristics as culture and identity, natural resources, and the true needs of the local populations [7].

The aim of this paper is to describe and analyse the impact of tourism activities on local development since the creation in Baja California Sur, Mexico of two development poles, Los Cabos and Loreto, which conform the paper's research cases. Two initial research questions inform the paper: Can tourism be made into an activity that fosters local development? If so, what are the different dimensions of local economic development in which tourism has generated the greater impact in the Los Cabos and Loreto CIPs?

The research employs an analytical-descriptive methodology which allows for the contextualisation of the development and evolution of tourism in the case studies on the basis of the estimation of economic indicators that allow the evaluation of tourism's impact on local development. A first moment was a thorough literature revision with the aim of bringing on board the required conceptual-theoretical support in the topic of CIPs. This was followed by a quantitative analysis of base don multivariate methods, specifically principal component analysis. The paper's first section deals with the context and evolution of the two CIPs under study. This is followed by the presentation of methodological and statistical aspects. The third section shows the estimated indicators and discusses results. The latter show that the exogenous and centralised policies, on which the tourism development model of Los Cabos and Loreto has rested, together with the trend of market forces and the power of capital, have generated polarised and asymmetrical economic growth. 


\section{THE OVERALL CONTEXT OF CIPS IN MEXICO.}

Tourism has been an important element in the Mexican government's economic strategy since the publication in 1978 of the first National Tourism Plan, wherein FONATUR, the national tourism board, was appointed its promoter and overseer. The development of regional tourism centres was seen by FONATUR as the key to increasing Mexico's high quality tourism offers, position the sector in new, higher value market segments and promote economic development so as to more fully integrate peripheral areas into the growing national economy [8]. The objective of the CIP policy was to detonate regional and local development on the basis of an indicative planning scheme, itself depending on significant state participation both in the construction of infrastructure and the attraction of foreign investment to the selected regions In this context tourism, as an economic activity, is orientated towards the generation of regional and local economic development, adopting a territorial framework if action the aim of which is to improve, collectively and lastingly, a community's welfare [9]. This implies that tourism need to consider both the potential and the existing capacities of the spatial economy, and those of economic, social, and institutional actors [10].

Thus, from the beginning, Mexican policy makers saw tourism as an alternative for the promotion of economic development, job creation, foreign exchange generation and regional development [11]. Given the serious payments and financial crises that the Mexican economy faced in the 1980s, tourism policy decidedly turned, specifically, to the development of mass tourism-friendly environments aimed primarily at the huge United States market. CIP policy was articulated on the basis of territorial, physical, and urbanistic considerations. In this way, tourism promotion became a matter of urbanization and the creation of adequate infrastructure as the means to expand tourism offerings [12]. On the assumption that public investment in infrastructure becomes a positive externality for large foreign investors, The Mexican government embarked on the construction of such tourism facilities as the international airports of San José del Cabo and Loreto, the Cabo San Lucas Marina, and the urbanisation of tourism areas in San José del Cabo and Nopoló (in Loreto). These public works came to be significant attractors for the principal actors in Mexican tourism: hotel chains, real estate and time-sharing developers, and tour operators, as it allowed them a significant measure of control of the market and gave them a leadership role in beach destinations built on the CIP model. As said before, generally speaking CIPs were created in enclave areas of inestimable natural and landscape value with a pronounced orientation towards the sun and beach international market, with the concomitant domination of the market by tour operators [13].

Several studies have underscored some of the negative results of the CIP policy. Villaseñor [14] tells that in Cancún the nature reserves and green areas indicated in the initial planning documents were not respected. Alongside the development of tourism facilities there grew an asymmetrical society with large marginalised areas, lacking any form of urban planning and adequate public services. Here lives $70 \%$ of the population of Cancún, mainly immigrants attracted by the possibility of finding a job. Similarly, Brenner [15] has pointed out that the Ixtapa Zihuatanejo CIP has faced strong immigration pressures, which have led to deficient urban development and severe social, economic and ecological conflicts that negatively bear on the population's quality of life. Among these are the excessive use of water by hotels, the degradation of natural landscapes, badly paid and unstable employment, a low proportion of the local population in the labour market and their nil participation in planning and development decision-making processes. Montaño et al. [16] found that Los Cabos has suffered great environmental damage, especially with respect to the overexploitation of underground water sources, contamination of the land, and loss of land and marine animal and vegetable 
species- As regards social aspects, the great increase in tourism activity aggravated social problems, brought to the fore issues such as drug addictions and insecurity and exerted enormous pressures on urban land and housing.

According to Mendoza et al. [17], the local population of Huatulco has a negative perception of the effects of tourism. Most locals express great displeasure at not having been taken into account in the planning and construction stages of the tourist project, and regard as insufficient and inadequate the wages and working conditions that the industry offers. They also show concern about the problems that tourism-led urban growth has brought them. The same research team Mendoza et al. [17] has looked at the Nayarit CIP (Bahía Banderas), where during and after construction the native population was displaced and serious damage to the ecosystem was effected. As is the case elsewhere, tourism urbanization created a huge city belts of extreme poverty that house the immigrant population.

As a result, the Mexican Competiveness Institute declared in 2013 that 'the CIP model runs against the current world trends in tourism, which above all values the search for the experience of nature and interactions with the local [3]'. Given this finding, it is evident that the th CIP model of tourism planning has been overtaken by events. The basic reason is its overarching concern for the development of the tourism site alone, without taking into consideration a host of key factors that can lead to adequate levels of local and spatial development, such as the socioeconomic conditions of local residents (with all that this implies) and the ecological sustainability of the area.

\section{THE INTEGRAL PLANNED CENTERS OF LORETO AND LOS CABOS.}

The Los Cabos and Loreto CIPs were created in 1976 by FONATUR, the Mexican government's Tourism Fund. Los Cabos is an internationally renowned tourism destination that includes the cities of San José del Cabo and Cabo San Lucas, now joined by a $33 \mathrm{~km}$. tourist corridor, was created by FONATUR in 1976 on the sites of what were then two small fishing villages between the sea and the desert. This destination appeals to middle and high income travelers, which secures it exceptionally high economic benefits and implies high levels of consumption [18]. The Loreto CIP is located towards the middle of the Baja California peninsula, along the Gulf of California coastline. It comprises a tourist corridor that joins the town of Loreto, the Nopoló tourist resort and a marina in Puerto Escondido. As such, its geographical location favors the combination of deep-sea fishing activities with leisure and nature tourism, as the area conjoins the sea, the desert and the Sierra de la Giganta mountain range. Loreto was in the 18th century the capital of the Californias, as its administrative brief ran as far north as the San Francisco Bay area; it also boasts a well-preserved Jesuit mission in the nearby sierras. As well, the area is part of the largest ecological reserve in Mexico: The Loreto Bay National Park. Loreto's natural market includes Mexican, American and Canadian tourists. However, despite receiving huge amounts of public investment, the area failed to take off as an important destination [19]. According to the original Tourism Plan (and FONATUR's projections), public investment in the Loreto CIP would become unnecessary by 1990, when tourist arrivals would reach 900,000 visitors. However, over 2015 the number of visitors was just 109,682 [4], showing that the reality is far beneath the original goals.

The relative stagnation of the Loreto CIP may obey multiple causes, among which we may list the following: i) a flawed planning process, devised exclusively in Mexico City government offices, which failed to generate the strategies that were needed successfully to promote the area in the projected market segments; (ii) the simultaneous construction of two CIPs in the same state (BCS), relatively near to each other (which fact from the beginning gave Los 
Table 1: Loreto and Los Cabos: participation in Mexico’s tourism GDP.

\begin{tabular}{ccccc}
\hline & \multicolumn{2}{c}{ Loreto } & \multicolumn{2}{c}{ Los Cabos } \\
\cline { 2 - 5 } Year & Million. USD. & \% national total & Million. USD. & \% national total \\
\hline 2010 & 110 & 0.13 & 2,785 & 3.28 \\
2011 & 215 & 0.23 & 3,176 & 3.4 \\
2012 & 223 & 0.23 & 3,217 & 3.37 \\
2013 & 282 & 0.27 & 3,810 & 3.65 \\
2014 & 259 & 0.25 & 3,622 & 3.44 \\
2015 & 216 & 0.23 & 2,980 & 3.11 \\
2016 & 205 & 0.23 & 2,792 & 3.17 \\
\hline
\end{tabular}

Sources: prepared by the authors based on Refs. [20] [21].

Cabos a competitive advantage over Loreto, as it was better known abroad and early on boasted fairly good travel connections), (iii) the marked preference of the private sector for Los Cabos over Loreto as an investment site, especially since the former began its strong process of consolidation in the early 1990s and, finally, (iv) the lack of sufficient scheduled flights between Loreto and the places of origin of its targeted visitors, i.e. the conundrum that 'there not enough flights because there are not enough hotel rooms, and there are not enough hotel rooms because there are not enough flights.' Thus, although both the Los Cabos and Loreto CIPs were planned as low density, high income destinations, to be provided with fivestar and grand tourism hotels that would house middle and high income tourists, their economic indicators (as compared with other Mexican CIPs) show a markedly asymmetrical development: while Los Cabos is Mexico's second most successful destination (after Cancún), Loreto has stagnated, registering low and sporadic growth rates. Those indicators show significant differences. While Los Cabos represents on average (between 2010 and 2016) about 3.34\% of Mexican tourism GDP, (see Table 1) the figure for Loreto is only $0.22 \%$; similarly, foreign Exchange earnings in Los Cabos amount to 67.4 million dollars per month, the Loreto's stand at only 1.75 million [20].

A main problem is that the tourism market has not been receptive to the several promotion and commercialization strategies that have been implemented for Loreto. This CIP began as a sun and sand destination, leaving aside the other, previously mentioned possible visitor attractions; it then sought to find its niche in the real estate market, in the construction of second homes and time-sharing apartments for foreign travelers. At present it seems to emphasize nature and cultural tourism, following its designation in 2012 by the national tourism secretariat (SECTUR) as a Pueblo Mágico (magic town).

\section{METHODS}

\subsection{Determination and estimation of variables}

This research is based on an analytical-descriptive methodology that relies on the application of principal component analysis (PCA). Data to construct the variables involved were 
obtained from such official sources as: Statistical Yearbooks [22], the Economic Census [23], the System of National Accounts [24], and the Tourism Statistical Data Books [25], among other. Once the relevant information had been gathered, the original data were analyzed in order to group them into two periods, 2000 and 2015, the years selected for the study.

In order to analyse the impact of tourism on the local development of the Los Cabos and Loreto CIPs, 36 variables were selected, all having to do with tourism activities; thus, all of them directly bear on the local development of the areas under study. Examples of these variables are: employment, entrepreneurial activity, urban furnishings and amenities, population, available land, education, economic conditions, unemployment, health indicators, migration and poverty rates. Given the large number of variables and likely high autocorrelation rates, principal component analysis (PCA) was used to group them according to those correlation estimates. Data for empirical analysis were obtained from both CIPs and PCA was estimated for both years. Since scale differs between the variables, data were standardised as follows:

$$
\mathrm{Y}_{\mathrm{i}}=\frac{\mathrm{X}_{\mathrm{i}}-\overline{\mathrm{X}}}{\sigma} \text {, where } \mathrm{Y}=\text { standardised value, } \mathrm{X}=\text { unstandardised value, } \overline{\mathrm{X}}=\text { mean, }
$$

$\sigma=$ standard deviation and variable.

Once the data were standardised, the PPA model was applied to p standardised variables $\left(Y_{1}, Y_{2}, \ldots, Y_{p}\right)$ initially correlated. From this was obtained a new number of k variables e variables, $\left(Z_{1}, Z_{2}, \ldots, Z_{k}\right)$, which are linear combinations of the $Y_{p}$ variables that explain the greater part of the Variance. The principal component model can be expressed in matrix form as follows:

$$
\left[\begin{array}{c}
Z_{1} \\
Z_{2} \\
M \\
Z_{k}
\end{array}\right]=\left[\begin{array}{cccc}
a_{1,1} & a_{1,1} & K & a_{1, p} \\
a_{2,1} & a_{2,2} & K & a_{2, p} \\
M & M & O & M \\
a_{k, 1} & a_{k, 2} & K & a_{k, p}
\end{array}\right]\left[\begin{array}{c}
Y_{1} \\
Y_{2} \\
M \\
Y_{p}
\end{array}\right]
$$

The model can also be expressed in linera form, in which case the first component is obtained as $Z_{1}=a_{1,1} Y_{1}+a_{1,2} Y_{2}+, \ldots,+a_{1, p} Y_{1}$; the second as $Z_{2}=a_{2,1} Y_{1}+a_{2,2} Y_{2}+, \ldots,+a_{2, p} Y_{2}$; and the same structure is repeated until the $\mathrm{k}$ variable, which corresponds to total principal components, can be written as:

$$
Z_{k}=a_{k, 1} Y_{1}+a_{k, 2} Y_{2}+, \ldots,+a_{k, p} Y_{p}
$$

The results of this analysis show that four components explain $100 \%$ of variance. Values do not exhibit great changes year on year, as variance is practically the same for each component.

\subsection{Statistical analysis}

Principals Component Analysis aims to build and synthesize homogeneous groups of data from a set of socioeconomic indicators and ensuring their quality, while at the same time reducing to a minimum the loss of original information (13). Thus, the effective reduction of the dimensions of information occurs upon selecting those factors that have greater incidence in terms of the explicative content of the set of variables. This was done through the identification of the correlation coefficients between the original variables and each on the explained variance components. As shown on Table 2, four components four components were that 
Table 2: Component analysis for the Baja California Sur CIPs, 2000 and 2015.

\begin{tabular}{|c|c|c|c|c|c|c|}
\hline \multirow{3}{*}{ Component } & \multicolumn{4}{|c|}{ Initial eigen values } & \multirow{2}{*}{\multicolumn{2}{|c|}{$\begin{array}{c}\text { Total explained } \\
\text { variance (Accumulated } \\
\text { percentage) }\end{array}$}} \\
\hline & \multicolumn{2}{|c|}{ Total } & \multicolumn{2}{|c|}{$\begin{array}{l}\text { Percentage of } \\
\text { variance }\end{array}$} & & \\
\hline & 2000 & 2015 & 2000 & 2015 & 2000 & 2015 \\
\hline $\begin{array}{l}\text { PC1: Spatial economic } \\
\text { dynamics }\end{array}$ & 22.51 & 22.80 & 62.52 & 63.34 & 62.52 & 63.34 \\
\hline PC2: Tourism activity & 8.24 & 7.55 & 22.89 & 20.98 & 85.41 & 84.31 \\
\hline $\begin{array}{l}\text { PC3: Spatial } \\
\text { development }\end{array}$ & 3.50 & 3.95 & 9.73 & 10.96 & 95.13 & 95.27 \\
\hline PC4: Social development & 1.75 & 1.70 & 4.87 & 4.73 & 100 & 100 \\
\hline
\end{tabular}

explain $100 \%$ of total variance; as well, each of them has a similar explicative value for each year. As mentioned, the years 2000 and 2015 constitute the temporal framework of this research, and the 36 variables (original data) considered were the same for each year. In order to define and interpret the four components the following concepts were used:

- The correlation coefficients between each original variable and each of the components obtained (denoted as factor loadings) with a value greater than 0.5 .

- The correlation matrix of the original variables.

- Factor rotation, done through the varimax orthogonal rotation method with Kaiser Normalization.

- In assigning a name or label to the principal component variables with greater correlation values were used, as it was found that the grouping process facilitates interpretation and allows the naming of each component.

The degree of representativeness of each of the components (i.e. their reliability) is obtained from the value of the variance associated with the variables under analysis. In this research, the representativeness of the first component is $62.5 \%$ for 2000 and $63.4 \%$ for 2015; the second component explains $21.89 \%$ of variance in 2000 and $20.98 \%$ in 2015 ; the third component accounts for $9.73 \%$ in 2000 and $11 \%$ in 2015 , while the fourth component explains $4.7 \%$ of variance in 2015 . From the factorial solution (Table 2) one can easily find the correlations between the original variables and each of the components, and thus the correspondence that holds for each variable and each of the four principal components. Having in mind that grouping the original variable around a component allows for easier interpretation (as well as naming the component), the original variables with the strongest correlations were taken.

Spatial Economic Dynamics, the first component or factor (PC1), groups variables that have to do with factors involved in the making of the region's socioeconomic trajectory, such as employment, infrastructure for business development and public investment. PC1 explains $62.52 \%$ of variance for 2000 and $63.3 \%$ for 2015 . It can be seen in Table 2 that the correlation coefficient (or factor loading) ranges from 0.708 to 0.997 ; thus, variables exhibit a strong relationship, indicating the existence of strong correlations between them and the estimated 
component. Too, the Pearson coefficient for PC1 is greater than 0.50 , which again indicates a positive correlation. On the other hand, the presence of variables with negative factor loading allows us to surmise that improvements in those variables that influence economic development will result in a reduction in the Marginalization Index (one of the main ways to measure poverty and socioeconomic vulnerability in Mexico). Overall, it can be seen that PC1 is the main engine of local development. The results make sense, since variables such as education; public investment, employment, and business development are strong promoters of development.

It can be seen in Table 3 that the correlation coefficient (factorial charge) for PC2 oscillates with between 0.708 and 0.997 , so that variables exhibit a strong relationship, showing a strong correlation between the variables under study and the value obtained for that component. As well, the Pearson correlation coefficient (for PC1) is higher than 0.50, which indicates a highly positive relation. On the other hand, the negative factorial charges allow the conclusion that as the variables that influence economic development (like employment, infrastructure, and government investment, among others) improve, the marginalisation index should decline.

Tourism Activity, shown as PC 2, explains for each year a little over $20 \%$ of variance, reflecting its relevance for the level of development. This component includes such variables as the population employed in the services sectors, the number of firms per thousand populations, the number of 5-Star hotels (and hotels in general), tourist arrivals, municipal budgetary income, immigration indices, population density and ageing rate (see Table 4). PC2 explains $22.89 \%$ of variance in 2000 and $20.98 \%$ in 2015 , with factor loadings between 0.590 and

Table 3: Factorial solution, 'Spatial Economic Dynamics', 2017.

\begin{tabular}{clll}
\hline Positive factor loadings & \multicolumn{2}{c}{ Negative factor loadings } \\
\hline 0.997 & Education & -0.947 & Marginalization Index \\
0.980 & Employment in construction & -0.903 & Distance municipal capital \\
0.958 & Food preparation establishments & & \\
0.953 & Public investment in housing & & \\
0.936 & Employment in commercial & \\
& activities \\
0.902 & Number of houses with telephone & \\
0.890 & Electrical system subscribers & \\
0.886 & Total population \\
0.886 & Population in employment & \\
0.878 & Population in the labour force & \\
0.834 & Number of banks \\
0.823 & Employment in manufacturing & \\
0.787 & Public investment in infrastruc- & \\
& ture (Fondo de Ramo 33) & \\
0.708 & Number of economic units & \\
\hline
\end{tabular}


Table 4: Factorial solution: 'Tourism activity' component.

\begin{tabular}{|c|c|c|c|}
\hline \multicolumn{2}{|c|}{ Positive factor loadings } & \multicolumn{2}{|c|}{ Negative factor loadings } \\
\hline 0.986 & Population born in another state & -0.923 & Ageing rate \\
\hline 0.934 & Tourists staying in hotels & & \\
\hline 0.930 & Five-star hotels & & \\
\hline 0.924 & Employment in hotels and restaurants & & \\
\hline 0.915 & Population density & & \\
\hline 0.770 & Municipal budgetary income & & \\
\hline 0.732 & Lodging and accommodation establishments & & \\
\hline 0.644 & Firms per thousands of population & & \\
\hline 0.590 & Travel agencies, auto leasing and marinas & & \\
\hline
\end{tabular}

0.986. The ageing rate exhibits a correlation coefficient of -0.923 , which presumably indicates that places with greater potential for tourism development show lower proportions of older people. They also tend to show high immigration indices. Together, PC1 and PC2 explain $85 \%$ of variance, indicating their relevance to this analysis. As mentioned above, PC1 explains - in average $-62.5 \%$ of variance, reflecting the great importance of this indicator for the analysis of the CIPs in Baja California Sur.

The 'Territorial Development' component (PC3) has positive factor loadings in three variables: number of dwellings occupied (0.949), size of territory (0.871) and rate of economic dependency (0.698). PC3 explains $9.72 \%$ of total variance in 2000 and $10.95 \%$ in 2015. While the fourth component, 'Social Development', incorporates two variables with positive factor loadings: total occupied housing (0.949) and total employment in the primary sector of the economy (0.797). PC4 explains $4.9 \%$ of total variance in 2000 and $4.7 \%$ in 2015. It is thus expected that the destinations under study register high values for this component, pointing to greater level of welfare.

\section{RESULTS: TOURISM IN LOCAL DEVELOPMENT}

In order to analyse with greater precision the characteristics of local economic development (LED) in the areas under study, Loreto and Los Cabos, we provide the relevant statistical data for the construction of four principal components, emphasizing those found to be of greater importance, Spatial Economic Development (PC1) and Tourism as a factor in development (PC2). These are shown on Tables 5 and 6. The results obtained for the four components allow the evaluation of levels of social development from looking at variables such as population, employment, tourism activity and others. They also permit us to analyse the variable with the largest impacts on spatial economic dynamics in the Loreto and Los Cabos CIPs. The Spatial Economic Dynamics component (Table 5) offers information on employment structure and sectoral shares for the main economic activities carried out in those CIPs, as well as some of the variables that influence local economic development. For the 2000 and 2015 periods an ongoing process of structural change is in evidence, as primary and secondary sector employment falls in favour of significant increases in trade and services, particularly those associated with tourism. This confirms the 'tertiarization' (or shift to the tertiary or services sector) of employment in both CIPs. 
A. Montaño, et al., Int. J. Sus. Dev. Plann. Vol. 14, No. 1 (2019)

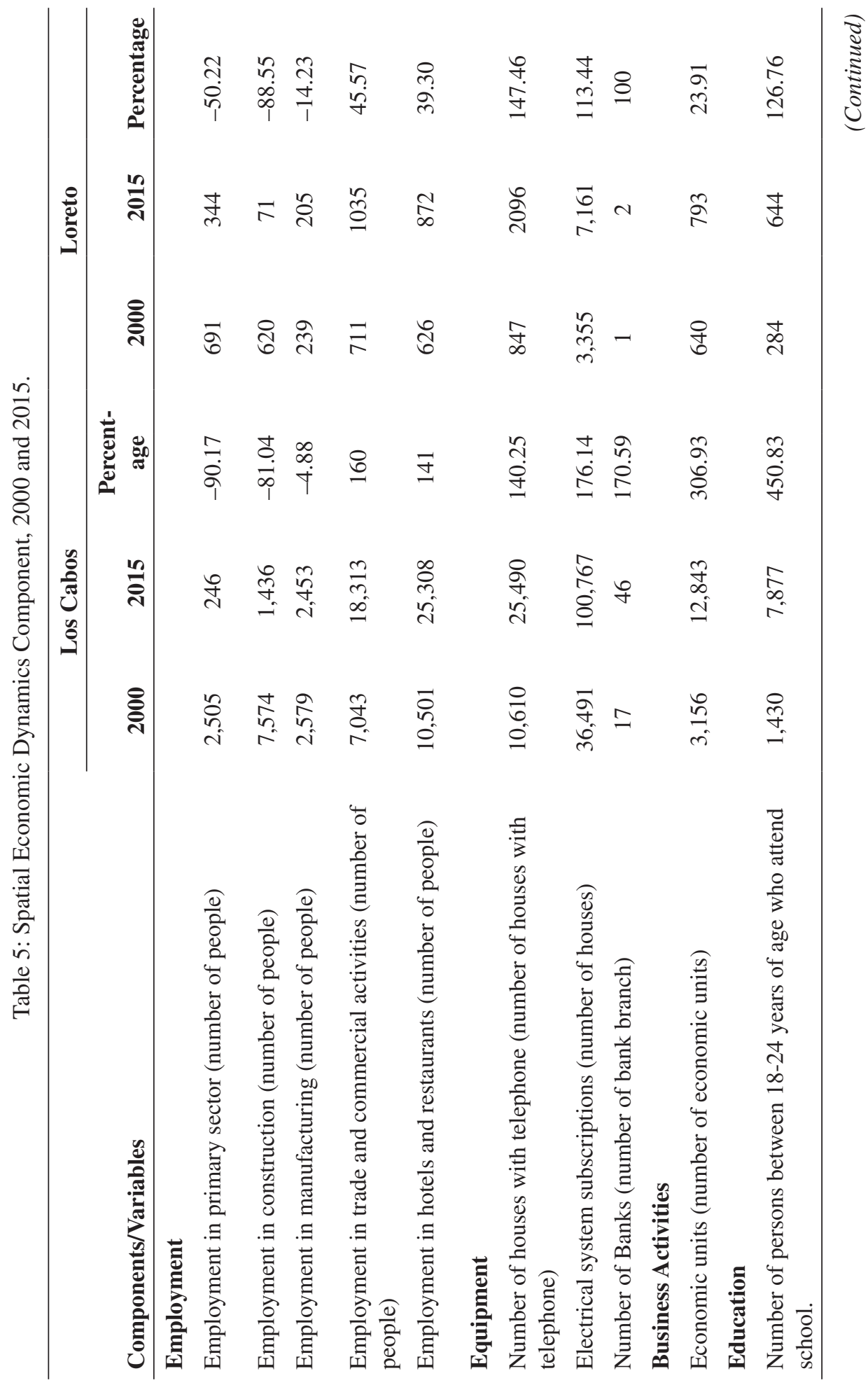




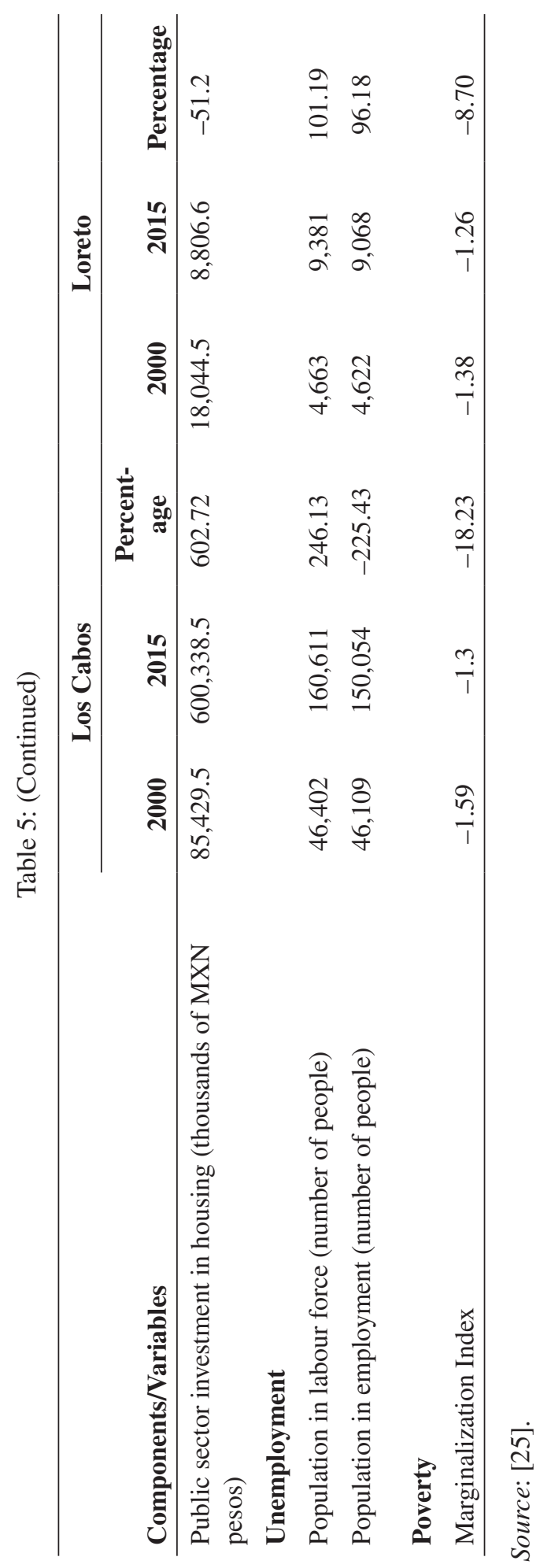


A. Montaño, et al., Int. J. Sus. Dev. Plann. Vol. 14, No. 1 (2019)

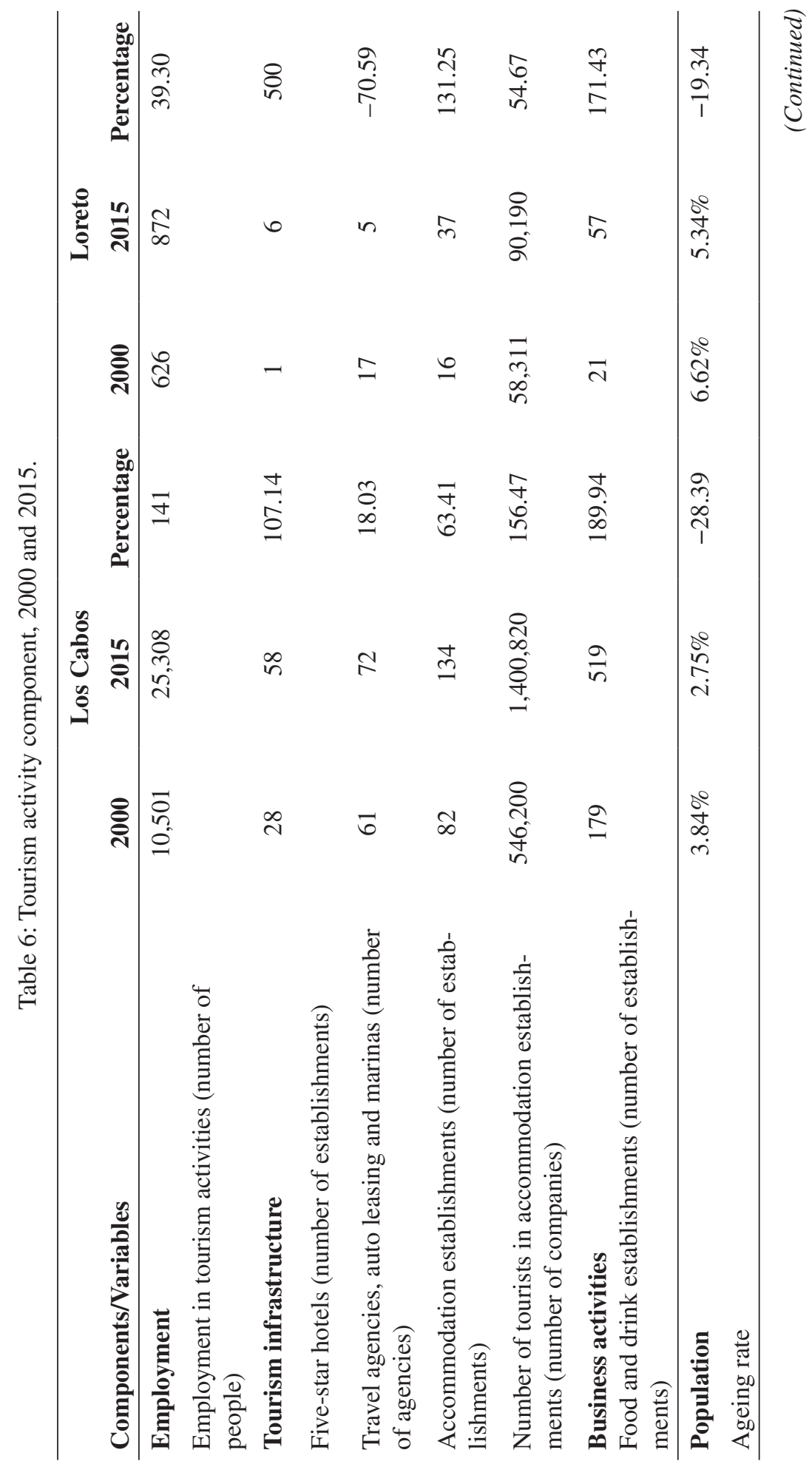




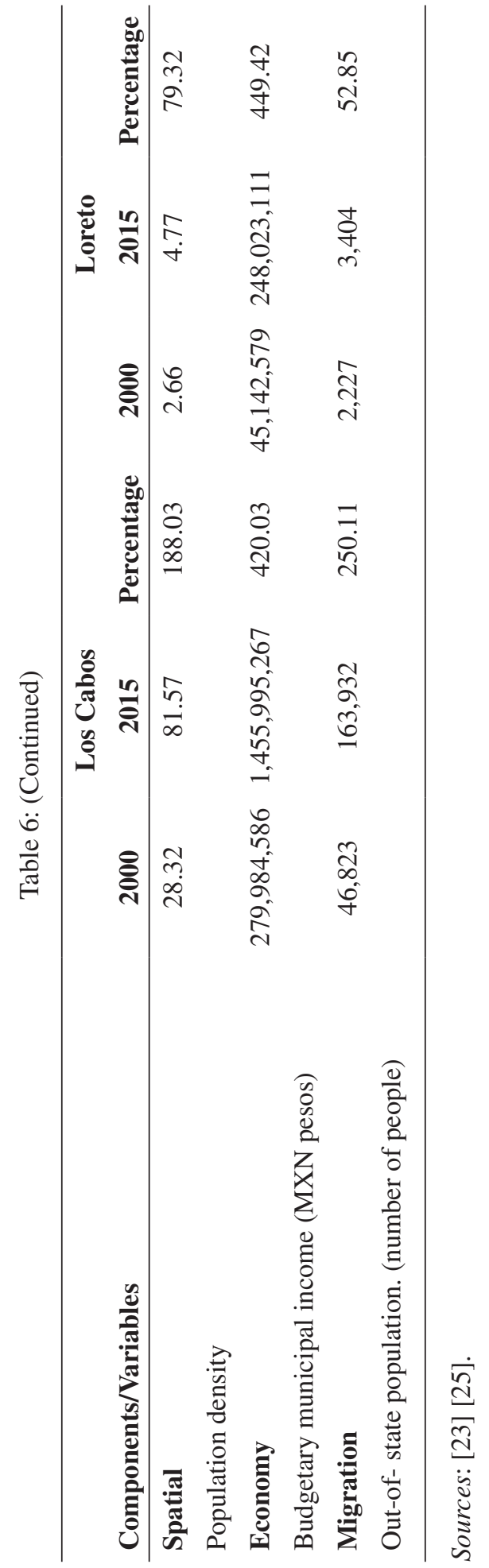


The buoyancy and dynamism of the Los Cabos economy is confirmed by the data available on equipment and business activity. For example, the number of subscribed users of the electrical grid (taken as a measure of economic activity) increased by $176 \%$, while the number of economic units rose by $111 \%$. In Loreto, in contrast, these indicators increased by $113 \%$ and $23.9 \%$, respectively. Similar changes are apparent when we look at total employment, which rose by $225 \%$ in Los Cabos, as against $96 \%$ in Loreto.

Comparatively speaking, since 2012 Loreto has made a slow recovery from the effects of the 2008 financial crisis, when it saw a significant drop in its tourism. Tourism flows to the Loreto CIP, relatively small, rose by 55\% from 2000 to 2015, for a yearly average of only $3.6 \%$; in the meantime, Los Cabos witnessed a rise of $12.6 \%$ per year. Another important difference is that Los Cabos tourism is mainly foreign (79\%), while visitors to Loreto tend to be primarily Mexicans (76.4\%). Differences in spending power and patterns are a relevant issue here. Indeed, the comparative summary of the PC2 component for the two CIPs under study leads us to the conclusion that - since its creation - the Los Cabos CIP has experienced a constant increase in the number of visitors; between 2000 and 2015, their numbers grew by $156.5 \%$. Los Cabos put its resilience to the test when Hurricane Odile hit the area in September, 2014: not only was it able to rebuild its tourism offerings; in fact, they increased. Between 2015 and 2017 tourism infrastructure grew significantly; during this period, 18 new hotels came online, adding 3,796 rooms to the Los Cabos stock [26]. This meant an increase of $29 \%$ over prior offerings, so that the number of rooms in this CIP rose to 18,000 units.

Total population has risen substantially in both CIPs but, again, an asymmetrical growth pattern is in evidence in the two tourist centres. The municipality of Los Cabos grew at almost exponential rates between 2000 and 2015, when overall growth was recorded at $172.7 \%$; on the way, it became the main population centre of BCS, overtaking the capital city, La Paz. During the same period the population of Loreto rose by $60 \%$, as it remained the state's smallest municipality. Investment has been historically concentrated in the southern part of the state of BCS, in Los Cabos and La Paz. Among the several factors that explain this phenomenon one may list demand conditions that arise from population growth and tourism activity, the multiplier effects of the construction sector, both in infrastructure and other building activities, and the growth of sectors directly tied with tourism, such as trade and transport services. In our view, however, the main factor has been the provision of infrastructure in the form, for example, the Los Cabos airports, the Marina, and the four-lane highways that join San José del Cabo - Cabo San Lucas and La Paz. These and other similar works have been key factors in tourism promotion and growth. As mentioned, tourism infrastructure is concentrated in Los Cabos, where $75 \%$ of the state's Five star are located. As well, 55\% of luxury food and drink establishment and the majority of business enterprises are to be found there [27] [28]. Meanwhile, the Loreto region has stagnated even though its growth indicators may surpass those of the rest of BCS's municipalities - bar Los Cabos, of course. With 163,932 , Los Cabos is also the BCS region with most non-native population: $43 \%$ in 2000 and $57 \%$ in 2015 . The opposite obtains in Loreto, where non-natives accounted for $21 \%$ of the population in 2000 and $24 \%$ in 2015.

The concentration of investment in the southern part of the state of Baja California Sur obeyed factors such as: the conjunction of demand (owing both the numbers of population and tourism activity), increases in aggregate demand resulting from the effects of the construction of tourism infrastructure and housing, and the growth of sectors directly linked with tourism, such as trade, services and transport [27] y [28]. In Loreto, on the other hand, a state of relative stagnation, or at best slow growth, has prevailed. The two CIPs also show 
differences in social conditions, according to the National Council for the Evaluation of Social Policies, which measures poverty and social vulnerability in Mexico's 32 states and over 2400 municipalities: the proportion of population in poverty in Loreto was $41.2 \%$ in 2000 and $41.3 \%$ in 2015; in Los Cabos, that percentage fell from $30.1 \%$ to $27.6 \%$ in the same period CONEVAL [29]. The rate of migration to Los Cabos is very high, and the municipality has the highest percentage of people born in states other than Baja California Sur. The proportion of people from out of state rose from $43 \%$ in 2000 to $57 \%$ five years later, for a total non-native population of 163,932. Again in contrast, Loreto has the state's lowest proportion of non-native population (21\% in 2000 and $24 \%$ in 2015).

Based on the arguments expressed herein and on tourism indicators for the two CIPs under study, such as participation in national tourism GDP, foreign exchange earnings and tourism flows, it is clear that this research can ratify the signal importance of Los Cabos for the tourist economy of Baja California Sur, as well as the small part that Loreto has played in it, and in Mexico's CIPs. Between 2010 and 2017, the participation of Los Cabos in the generation of foreign exchange (FX) by CIPs ranged from 14.6 to $27.7 \%$, and this implies that this CIP contributes $5.4 \%$ of total FX earned in Mexico by tourism [4]. Loreto's contribution is only $0.5 \%$, on average, which is of small significance given the great importance attributed to CIPs. Finally, statistical indicators reflect the share of foreign tourism for each destination. In 2017, the participation of Los Cabos in sun and beach tourism was 5.4\% of the total, surpassed only by Cancún, whereas Loreto's share was a measly $0.38 \%$ [4].

The data presented on Fig. 1 summarizes the PC that refers to tourism activity. It shows that from its beginning as a CIP Los Cabos has recorded an ongoing increase in visitor flows. In this way, between 2000 and 2015 the number of tourists (mainly foreigners) rose by $156 \%$. As said, the resilience of this CIP was put to the test by Hurricane Odile, and (with large funding from the Mexican government) Los Cabos passed this test and restarted it growth process shortly thereafter. Between 2015 and 2018, hotel infrastructure has grown significantly. During this period 18 new hotels came into operation, adding a further 3,796 rooms to the existing stock, which grew by $29 \%$ in that period, for a total of 18,000 [26].

Population also shows asymmetrical behaviour in Los Cabos and Loreto. It has grown explosively in the first case, as shown by the data gathered in the Population and Housing

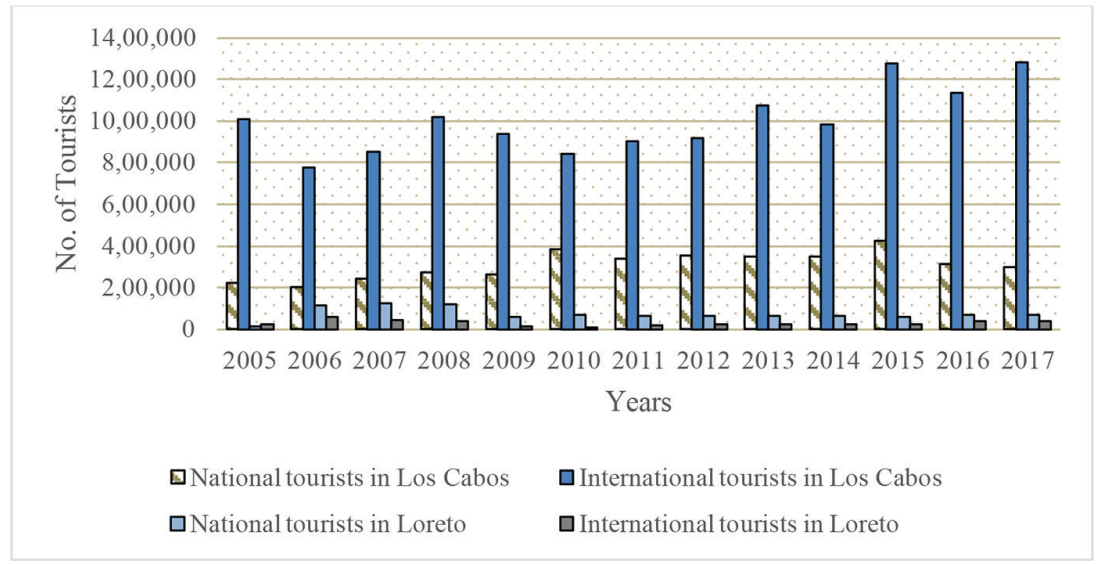

Figure 1: Number of tourists on the Loreto and Los Cabos CIPs, 2005-2015.

Source: [20]. 
Census carried out by INEGI in 2000 the Los Cabos municipality had a resident population of 105,469 ; by 2015 , it had increased to 287,621 . In that year it became the municipality with the highest population density in the state of Baja California Sur, with 81.6 persons per $\mathrm{km}^{2}$. In contrast, Loreto had 11,812 inhabitants in 2000 , rising to 18,912 by 2015 but remaining the least peopled municipality in the state.

\section{CONCLUSIONS}

1. In answer to the questions posited at the beginning of the paper, it may be concluded the principal component analysis carried out in this research underscores the paramount role displayed by the Spatial Development component in the tourism development model of the two CIPs under study, Los Cabos and Loreto. By itself, the aforementioned component accounts for more than half of total variance. This fact is particularly telling for the Los Cabos CIP, where most indicators that measure the economic dimension point to successful outcomes. Nonetheless, the research also discloses the existence of deficient outcomes in both CIPs when the social dimension is analysed.

2. The analysis of principal components and tourism macroeconomic indicators for the two CIPs show the presence of asymmetrical growth processes. While Los Cabos is the second most successful CIP in Mexico, Loreto, 40 years after its creation, is still mired in relative stagnation, as evinced by its low growth rate. This is true in spite of the large amounts of public (and, in smaller terms, private) investment that this destination has received over the years. Loreto has thus been unable to realize FONATUR's expectations, despite exhibiting economic indicators that - under most circumstances - would be very satisfactory.

3. The establishment of meaningful economic and social relations between CIPs and the surrounding territory has been limited, as have been the effects of aggregate (sectoral) demand on local productive services. In Los Cabos, it has been difficult to balance the conservation of natural and sociocultural resources with the economic growth generated by tourism. The relative backwardness of Loreto is, explained, in part, to inadequate processes of strategic planning, as reflected by the creation of two CIPs in the same state. The more favourable circumstances of Los Cabos made it the winner in an unequal match with Loreto. However, one should also note the uncertain reception foreign tourism of Loreto's offerings, first as a sun and sand destination, then as a second residence site, and now as a Pueblo Mágico.

4. In general, Mexican CIP tourism policy has been able to reach its macroeconomic goals (foreign exchange generation, job creation, GDP share, etc.). However, as far as regional and local development is concerned, success has been limited, and less than expected. The main reason for this is that CIP are part of a development model that is exogenous to tourism-receiving communities, and has thus proved to be insufficient as an answer to local requirements. This points to the need to put in place policies with greater local flavour that may be joined with central government efforts and result in the generation of tourism models that are more responsive to social and ecological needs.

\section{REFERENCES}

[1] Mendoza, M. \& González, J., Impactos socioculturales del turismo en el Centro Integralmente Planeado Loreto, Baja California Sur, México. Percepción de los residentes locales. Teoría y Praxis, 10(16), pp. 117-146, 2014. 
[2] Jiménez Baños, P. \& Bote Gómez, (dir). Los centros integralmente planeados de México (CIP'S) y los factores que limitan el crecimiento turístico del centro Bahías de Huatulco [tesis doctoral]: Universidad Antonio de Nebrija; 2010 [citado el 21 de septiembre del 2018]. Recuperado a partir de: https://dialnet.unirioja.es/servlet/tesis?codigo $=118922$

[3] IMCO, Instituto Mexicano para la Competitividad. Nueva política turística para recuperar la competitividad del sector y detonar el desarrollo regional; Ciudad de México, 2013.

[4] SECTUR, Compendio Estadístico de Sector Turismo de México, Secretaría de Turismo; Ciudad de México, 2017.

[5] Dávila, A., Centro Integralmente Planeados (CIPS) en México: las piezas del proyecto turístico de FONATUR. [Internet]. 2014 [citado 21 de septiembre del 2018]. Recuperado a partir de: http://hdl.handle.net/2099/15985

[6] Montaño Armendáriz A, Modelo de Desarrollo Económico Local para la Diversificación de la Estructura Productiva y la Articulación del Tejido Empresarial en Baja California Sur [Doctoral Thesis]: Universidad Autónoma de Baja California; 2014, http://www.eumed.net/tesis-doctorales/2014/mama/index.htm

[7] Baños, J., Ocupación del territorio litoral en ciudades turísticas de México. Revista Bitácora Urbano Territorial, 1, pp. 41-52, 2012.

[8] Tulio, M. \& Santamaría, A., Los Centros Integralmente Planeados (CIP’S) en México. Revista Latino-americana de Turismología, 1(1), pp. 36-53, 2015.

[9] Pike, A., Marlow, D., McCarthy, A., O'Brien, P. \& Tomaney, J., Local institutions and local economic development: The Local Enterprise Partnerships in England, 2010. Cambridge Journal of Regions, Economy and Society, 8(12), pp. 185-204, 2015. https://doi.org/10.1093/cjres/rsu030

[10] Butler, G. \& Rogerson, C., Inclusive local tourism development in South Africa: Evidence from Dullstroom. Local Economy Sage Journal, 31(1-2), pp. 264-281, 2016. https://doi.org/10.1177/0269094215623732

[11] Amaya, C., Sosa, A. \& Moncada, P., Determinantes de competitividad turística en destinos de sol y playa mexicanos. Región y sociedad, 29(68), pp. 279-315, 2017.

[12] Montaño, A., Ivanova, A. \& Serrano, R., Desarrollo de destinos turísticos consolidados: una visión desde la sustentabilidad y resiliencia, 1st. edn. Los Cabos, BCS: UABCS, 2017.

[13] Honey, M. \& Krantz, D., Modelos Alternativos y Mejores Prácticas para el Turismo Costero Sostenible: Un Marco para la Toma de Decisiones en México. [Foro] Center for Responsible Travel. 15 de marzo de 2012. [cited on 17th. January 2018]. Retrieved from http://www.responsibletravel.org

[14] Villaseñor, B., Turismo y globalización. En: Camelo J., Ceballos L. Coordinadores. Desarrollo sustentabilidad y turismo: una visión multidisciplinaria, 1ra edn. México UAN, pp. 129-157, 2012.

[15] Brenner, L., Modelo para la evaluación de la "sustentabilidad" del turismo en México con base en el ejemplo de Ixtapa Zihuatanejo. Revista Investigaciones geográficas, 18(39), pp. 139-158, 1999.

[16] Montaño, A., Ivanova, A., Rodriguez, I., Pérez, J. \& Martínez, J., Touristic destinations and coastal cities: evaluation of the integrally planned center Los Cabos, México forty years from its foundation. International Journal of Sustainable Development and Planning, 12(8), pp. 1348-1358, 2017.

[17] Mendoza, M., Monterrubio, J. \& Fernández, M., Impactos sociales del turismo en el Centro Integralmente Planeado (CIP) Bahías de Huatulco, México. Revista Gestión turística, 12(15), pp. 47-73, 2011. 
[18] Benseny, G., El turismo en México. Apreciaciones sobre el turismo en espacio litoral. Aportes y Transferencias, 11(2), pp. 13-34, 2007.

[19] De Sicilia, R., El Corredor Turístico de Loreto-Nopoló-Puerto Escondido, Baja California Sur, en el Contexto de los Centros Integralmente Planeados. Cuadernos de Turismo, 5, pp. 53-68, 2000.

[20] SECTUR, Compendio Estadístico del Sector Turismo de México, Secretaria de Turismo; Ciudad de México, 2018.

[21] SECTUR [Internet], Estadísticas de actividad turística en los CIPs y PTIs, destinos de FONATUR; 2017 [citado 21 de septiembre 2018]. Recuperado a partir de: https://datos. gob.mx/busca/dataset/estadisticas-de-actividad-turistica-en-los-cips-y-ptis-destinosde-fonatur

[22] INEGI, Anuarios Estadísticos y Geográficos de Baja California Sur 2000-2015; La Paz Baja California Sur México, 2016.

[23] INEGI, Censo Económico: La Paz Baja California Sur México, 2015.

[24] INEGI [Internet], Instituto Nacional de Estadística y Geografía. Sistemas de Cuentas Nacionales, 2018[citado 21 de septiembre 2018] Recuperado a partir de: http://www. inegi.org.mx

[25] SECTUR, Compendio Estadístico de Sector Turismo de México, Secretaría de Turismo; Ciudad de México. 2016.

[26] Fideicomiso de Turismo en Los Cabos [Internet], Los Cabos evolución turística 20032017, Marketing Consultants, 2017 [citado 21 de septiembre 2018] Recuperado a partir de: http://www.mktconsultants.com.mx

[27] INEGI [Internet], Unidades económicas según criterios seleccionados; 2017 [citado 21 septiembre 2018]. Recuperado a partir de: http://www.beta.inegi.org.mx/app/mapa/denue/

[28] SECTUR, Compendio Estadístico de Sector Turismo de México, Secretaría de Turismo; Ciudad de México, 2015.

[29] CONEVAL [Internet], Consejo Nacional de Evaluación de la Política de Desarrollo Social; 2018 [citado 03 octubre 2018]. Recuperado a partir de: https://coneval.org.mx/ Medicion/Paginas/Pobreza-municipal.aspx 